\title{
Impact of Macroeconomic and Demographic Variables on the Stock Market: Evidence from Tunisian Crisis
}

\author{
Sirine Ben Yaâla ${ }^{1} \&$ Jamel Eddine Henchiri ${ }^{1}$ \\ ${ }^{1}$ UR.RED, Higher Institute of Management, University of Gabes, Tunisia \\ Correspondence: Sirine Ben Yaâla, UR.RED, Higher Institute of Management, University of Gabes, Tunisia. \\ E-mail: Sirine17@live.fr
}

Received: June 14, 2016

Accepted: July 16, 2016

Online Published: July 25, 2016

doi:10.5539/ijef.v8n8p194

URL: http://dx.doi.org/10.5539/ijef.v8n8p194

\begin{abstract}
This study aims to analyze the long-run as well as the short-run relationship between macroeconomic, demographic variables and the Tunisian stock market for the period subsequent to the financial crisis. Monthly data over the period 2008-2014 and ARDL model have been employed. Results indicate that the Tunisian stock market index, macroeconomic and demographic indicators are cointegrated and, therefore, a long-run relationship exists between them. The long-run coefficients suggest that budget deficit, inflation rate and the number of unemployed graduates had a negative effect, otherwise, money supply and the number of non-resident entries had a positive effect on the Tunisian stock market. Moreover, results from the error correction model show that the Tunisian stock market index is influenced positively by money supply and second order difference of the number of unemployed graduates and negatively by first and second order difference of money supply, inflation rate, first order difference of number of non-resident entries and the number of unemployed graduates.
\end{abstract}

Keywords: macroeconomic variables, demographic variables, Tunisian stock market, ARDL

\section{Introduction}

Stock market plays a noteworthy role in the boost and the development of the economy through mobilizing domestic savings and attracting foreign capital. In an efficient stock market, equity prices adjust rapidly to the arrival of new information, thus, stock prices must reflect all available information.

Supported by Fama (1970), the efficient market hypothesis (EMH), specifically semi-strong form efficiency, states that equity prices should incorporate all relevant information including publicly available information.

Also, the economic theory advanced that the fundamental value of stock should reflect future expectation profits and firms' performance. As a result, if stock prices reflect these assumptions, then it should be considered as a leading indicator for the real economic activities. Therefore, the dynamic interactions between market indicators and share prices are important in the formulation of the nation's macroeconomic policy.

In this paper, we aim to analyze the long-run as well as the short-term dynamics among macroeconomic variables such as budget deficit, money supply, interest rate, inflation rate, exchange rate and mine production index, demographic indicators like number of non-resident entries and number of unemployed graduates and the Tunisian stock market index for the period subsequent to the financial crisis.

The contributions of this study are twofold. First of all, our empirical study gives us insight on a set of macroeconomic and demographic factors determining the stock market index. Identified indicators provide useful signals on the evolution of stock price and their monitoring could contribute to a greater stability in stock market. Unlike the conventional research, in this paper, we apply the Auto Regressive Distributed Lag (ARDL) approach proposed by Pesaran (2001) to examine the long-run and the short-run relationship between macroeconomic, demographic variables and the Tunisian stock market index.

The rest of the paper is organized as follows. Section two summarizes the literature relating macroeconomic and demographic factors to stock market. Then, we present the sample and the methodology in section three. Section four reports empirical results and finally section five concludes the research and provides some recommendations and policy implications. 


\section{Literature Review}

In earlier literature, several researches have been conducted to analyze the link between market indicators and stock market. This section is related to the literature on the role played by macroeconomic factors namely budget deficit, money supply, interest rate, inflation rate, exchange rate and industrial production index, and demographic factors such as number of non-resident entries and number of unemployed graduates in explaining the stock market index.

\subsection{Budget Deficit and Stock Prices}

The link between budget deficit and stock market index has inspired both empirical and theoretical researches. The study conducted by Greenspan and Allen (1995) defend the idea that the reduction in budget deficit leads to lower inflation expectations which can have adverse effects on stock prices. Indeed, decrease in inflation expectations can reduce the value of shares because the real value of debt increases, thus reducing the company's value. In addition, a lower inflationary expectation reduces nominal interest rates which may cause the rise in stock prices because the lowest rates cause the assessment of future cash flows of companies. But inflationary expectations can also reduce the future cash flows which could decrease equity price.

According to Ball and Mankiw (1995) an increase in budget deficit causes a higher tax rate, which leads to reduce current consumption and therefore lower stock prices and vice versa. This explanation is considered by the notion of Ricardian Equivalence.

Quayes (2010) investigated the relationship between budget deficit and share prices by incorporating the effects of demographic structure and inflation. The results from cointegration analysis underline a negative link between inflation, budget deficit and stock prices.

By employing Auto Regressive Distributed Lag (ARDL) approach and Vector Error Correction Model (VECM) on annual data from 1988 to 2012, Joshi and Kumar (2015), studied both the long-run and the short-run relationship between Indian stock prices and budget deficit. The ARDL results show that budget deficit influences negatively stock price only in the long-run. However, the VECM results suggest a significant relationship in the short-term.

Subsequently, we can formulate the following hypothesis:

H1: A negative relationship exists between budget deficit and stock market index.

\subsection{Money Supply and Stock Prices}

Over the few decades, a number of studies have been conducted to analyze the nature of the relationship between money supply and equity prices. Namely, Ratanapakorn and Sharma (2007) examined the short-term and the long-term relationship between the US stock market index and macroeconomic variables using monthly data from 1975 to 1999. By employing Johansen technique and error correction model, they found that stock prices respond positively to industrial production, inflation, money supply, short-term interest rates and the exchange rate, but negatively correlated with the long-term interest rate. Granger causal analysis reveals a long-term unidirectional causality from macroeconomic variables to stock prices.

Hosseini et al. (2011) suggested that money supply is likely to affect the stock market index through three ways. First, change in the money supply may be associated with an unexpected increase in inflation and therefore affects negatively the stock market. Second, the money supply can positively influence the stock market index through its effect on economic activity. Finally, the portfolio theory predicts a positive relationship between money supply and changes in stock prices.

Hussain et al. (2012) ascertained that stock price in Pakistan is positively related to foreign exchange rate, imports, interest rate, and wholesale price, but negatively to the industrial production. The results of Granger Causality showed that money supply and wholesale price have bi-directional relation while exchange rate, foreign exchange reserve and imports have uni-directional relationship with the stock prices.

Forson and Janrattanagu (2013) studied the long-term relationship between the Thailand stock market (SETI) and macroeconomic variables using monthly data covering a period of 20 years from January 1990 to December 2009. The variables included in the analysis are the money supply, the consumer prices index, the interest rate and the industrial production index. The results indicate that the selected variables are cointegrated and a significant and positive relationship exists between the money supply and stock index. Hence, we can develop the following hypothesis:

H2: A positive relationship exists between money supply and stock market index. 


\subsection{Interest Rate and Stock Prices}

Other studies focused on the effect of interest rate on stock market. Hamrita and Trifi (2011) had explored the relationship between interest rate, exchange rate and stock prices in the United States during a period of 18 years from January 1990 to December 2008. They noted a negative correlation between interest rates and stock prices. Indeed, the rise in interest rates reduces the present value of future dividends, resulting in lower stock prices. On the other hand, a drop in interest rate inspires investors to create projects, providing in higher stock prices.

Based on monthly data ranging from January 1988 to March 2003, Alam (2009) examined the relationship between equity prices and interest rates for fifteen developed and developing countries: Australia, Bangladesh, Canada, Chile, Colombia also, Germany, Italy, Jamaica, Japan, Malaysia, Mexico, Philippines, South Africa, Spain and Venezuela. He concludes that changes in interest rates negatively impact stock prices.

Sarbapriya (2013) studied also the relationship between interest rates and stock prices in the Indian market during the period 1990-91 to 2010-11. Results from regression analysis suggest an inverse relationship among variables. However, no causal relationship exists between interest rates and stock prices.

Mahmudul and Gazi (2009) in their study based on monthly data from January 1988 to March 2003 found that the interest rate had a negative effect on the stock prices for Australian markets, Bangladesh, Canada, Chile, Colombia, Germany, Italy, Jamaica, Japan, Malaysia, Mexico, Philippines, South Africa, Spain and Venezuela.

Depending on the earlier results, we proceed by specifying the following hypothesis:

H3: A negative relationship exists between interest rate and stock market index.

\subsection{Inflation Rate and Stock Prices}

Malkiel (1982) argued that inflation rate had a negative effect on the assets prices. This is due to two reasons. First, an increase in the inflation rate tends to increase interest rate, which leads then to a drop in stock prices. Second, an increase in the inflation rate can reduce profit margins for special groups of companies like utilities, providing a higher share prices.

Fama (1981) advanced that the negative link between inflation and stock prices reflects the positive relation between equity profitability and real economic activity. Increasing inflation led to a weaker expected economic activity and an uncertainty about the future monetary situation that raised the risk premium of the investors, decreasing stock prices.

The negative relationship between stock prices and inflation was also confirmed and reinforced by the studies of Lintner (1973), Jaffe and Mandelker (1977) and Fama and schwert (1977).

Moreover, Akbar et al. (2012) linked between Karachi stock exchange index and macroeconomic variables by employing vector error correction model (VECM). The empirical results indicate a long-run equilibrium relationship between variables namely money supply and short-term interest rate were positively related while inflation and foreign exchange rate were inversely related to stock market index.

By Referring to monthly data from January 1974 to December 1998 and to the cointegration test of Johansen, Kim (2003) admits that the market index S\&P 500 is positively correlated to industrial production, but it is negatively related to the real exchange rate, interest rates and inflation.

Thus, the fourth hypothesis addressing the issue of the inflation rate is formulated as follows:

H4: An inversely relationship exists between inflation rate and stock market index.

\subsection{Exchange Rate and Equity Prices}

The portfolio approach postulates that changes in the stock price movements influence the exchange rate through portfolio adjustments (inflows/outflows of foreign capital). Indeed, foreign capital inflows will increase as far as stock prices follow an upward movement. However, the decline in stock prices would diminish the wealth of the national investor, leading to a decline in the demand for money and monetary authorities reduce the interest rates to alleviate this situation, which causes the output of capital and therefore currency depreciation.

Investigating the effects of changes in exchange rate on stock prices, Mukherje and Naka (1981) studied the long-term relationship between Tokyo stock exchange and macroeconomic indicators including the exchange rate. By applying the Johansen cointegration test, they found that exchange rate affect positively stock prices. This positive relationship is explained by the fact that Japan is considered a totally exporting country: the depreciation of the national currency will promote exports and hence the rise in stock prices.

Similary, Islam et al. (2004) investigated the long-run relationship between the Thailand stock market and 
macroeconomic factors between 1992 and 2001 using Engle-Granger test and cointegration method. Cointegration analysis indicates a positive long-run relationship between Thailand stock market index, interest rate, price earning ratio, foreign exchange rate and market capitalization and a negative long-run dynamics with the consumer price index.

Accordingly, we propose the next hypothesis:

H5: A positive relationship exists between exchange rate and stock market index.

\subsection{Industrial Production and Stock Prices}

Industrial production is considered as one of the measures of the economic activity. It affects stock prices through its influence on the future cash flows. Thus, it is expected that the increase in industrial production is positively related to stock prices.

In the Indian context, Naik and Padhi (2012) examined the relationships between stock market index (BSE Sensex) and five macroeconomic variables (wholesale price index, industrial production index, treasury bills rates, money supply and exchange rates) using Johansen's co-integration and VECM. Their analysis revealed that the selected variables and the stock index are cointegrated and therefore a long-term equilibrium relationship exists between them. They showed that stock prices were positively related to money supply and industrial production index and negatively associated to inflation rate.

Nishat and Shaheen (2004) examined whether macroeconomic factors can significantly explain the Karachi stock exchange index during 1973:1 to 2004:4. Results indicate that industrial production was positively linked but inflation was negatively related to stock prices.

By adopting the methodology ARDL, AL-Adaylah (2015) analyzed the empirical relationship between market indicators (industrial production, money supply, stock market capitalization and price earning ratio) and the Omman Stock Exchange index. Empirical results showed a long-term positive correlation between stock market capitalization, money supply, industrial production index and the stock market index. However, a negative and statistically significant relationship was detected between the price earning ratio and the index (ESA).

According to the previous results, we chose to test the following hypothesis in the Tunisian context:

H6: A positive relationship exists between industrial production and stock market index.

\subsection{Number of Non-Resident Entries and Stock Prices}

The tourism sector is considered among the most important sector in the economy. Its development can be appreciated by the increasing of the number of non-resident entries.

Indeed, the rise of the numbers of non-resident entries tends to increase consumption and demand for goods and services, leading to higher earnings and stock prices. In the present studies, we believe that the number of non-resident entries affect positively the Tunisian stock market. Hence our research hypothesis is as follows:

H7: A positive relationship exists between the number of non-resident entries and stock market index.

\subsection{Number of Unemployed Graduates and Stock Prices}

In the Tunisian context, unemployment especially among young graduates is considered among the causes of economic recession in the country since it causes the decline in demand for goods and services and the drop of corporate profits.

Consistent with the above argument, we state the next hypothesis:

H8: A negative relationship exists between number of unemployed graduates and stock market index.

\section{Data and Methodology}

\subsection{Data}

Our sample consists on macroeconomic data (budget deficit, money supply, interest rate, inflation rate, exchange rate and mine production index), demographic variables (number of non-residents entries and number of unemployed graduates) and the Tunisian stock market index.

We use Monthly data spanning from January 2008 to December 2014. Data were gathered from four different sources namely the National Institute of Statistics, the Tunisian Central Bank, the Ministry of Finance website and the Tunisian stock exchange.

In order to streamline the data, all variables were expressed on growth rate except for interest rate, inflation rate and exchange rate which are on real value. 
The description of all variables appears in the Table 1 bellow.

Table 1. Data description

\begin{tabular}{ll}
\hline Acronyms & Variables description \\
\hline TUNINDEX & Growth rate of Tunisian stock market index \\
DEF & Growth rate of budget deficit \\
M2 & Growth rate of money supply \\
INT & Real interest rate \\
INFL & Real inflation rate \\
EXC & Real exchange rate EUR/TND \\
MPI & Growth rate of mine production index \\
NRES & Growth rate of number of non-resident entries \\
UNEMP & Growth rate of number of unemployed graduates \\
\hline
\end{tabular}

\subsection{Methodology}

In this study, we employ the Auto regressive distributed Lag (ARDL) bound test approach proposed by Pesaran (2001). This methodology is relatively efficient in small samples (Cheung \& Lai, 1993). Unlike conventional method of cointegration (Engle \& Granger, 1987; and Johansen, 1991), ARDL model can accommodate greater number of variables. Moreover, the ARDL method is applicable to any order of integration, purely I (0), purely I (1) or mixed integrated. To this end, Augmented Dickey Fuller unit test is performed in advance.

To analyze the relationship between macroeconomic, demographic variables and the Tunisian stock market index, we estimate the following ARDL model.

$$
\begin{aligned}
& \Delta(\text { TUNINDEX })_{t}=\alpha_{1,0}+\sum_{i=1}^{p 1} \beta_{1,1} \Delta(\text { TUNINDEX })_{t-i}+\sum_{i=1}^{p 1} \beta_{1,2} \Delta(D E F)_{t-i}+\sum_{i=1}^{p 1} \beta_{1,3} \Delta(M 2)_{t-i} \\
& +\sum_{i=1}^{p 1} \beta_{1,4} \Delta(I N T)_{t-i}+\sum_{i=1}^{p 1} \beta_{1,5} \Delta(I N F L)_{t-i}+\sum_{i=1}^{p 1} \beta_{1,6} \Delta(E X C)_{t-i}+\sum_{i=1}^{p 1} \beta_{1,7} \Delta(M P I)_{t-i} \\
& +\sum_{i=1}^{p 1} \beta_{1,8} \Delta(N R E S)_{t-i}+\sum_{i=1}^{p 1} \beta_{1,9} \Delta(\text { UNEMP })_{t-i}+\delta_{l, l}(\text { TUNINDEX })_{t-1}+\delta_{l, 2}(D E F)_{t-1}+\delta_{l, 3}(M 2)_{t-1} \\
& +\delta_{l, 4}(\text { INT })_{t-1}+\delta_{l, 5}(\text { INFL })_{t-1}+\delta_{l, 6}(E X C)_{t-1}+\delta_{l, 7}(M P I)_{t-1}+\delta_{l, 8}(N R E S)_{t-1}+\delta_{l, 9}\left(\text { UNEMP }_{t-1}+\epsilon_{1, t}\right.
\end{aligned}
$$

Where:

$\Delta$ : first difference operator;

$\epsilon_{1,1}:$ Disturbance term;

$\alpha_{1,0}$ : constant;

$\mathrm{P}_{1}$ : optimum lag length.

Among the preliminary stages of the ARDL approach is to test the existence of long-term cointegration relationship between variables. For this purpose, the "Bounds test" is used to obtain the F-statistic value. This test considers both levels of integration of variables I ( 0 ) and I (1). Test assumptions are stated as follows:

H0: $\delta_{1,1}=\delta_{1,2}=\delta_{1,3}=\delta_{1,4}=\delta_{1,5}=\delta_{1,6}=\delta_{1,7}=\delta_{1,8}=\delta_{1,9} \quad$ (No cointegation relationship)

H1: $\delta_{1,1} \neq \delta_{1,2} \neq \delta_{1,3} \neq \delta_{1,4} \neq \delta_{1,5} \neq \delta_{1,6} \neq \delta_{1,7} \neq \delta_{1,8} \neq \delta_{1,9}$ (Cointegration relationship exist)

The null hypothesis of no cointegration is rejected only if the calculated F-statistic value is greater than the upper bound critical value.

Once the "bounds test" witnesses the existence of cointegration relationship, we proceed to estimate the long-run relationship.

$$
\begin{gathered}
\Delta(\text { TUNINDEX })_{t}=\alpha_{1}+\sum_{i=1}^{p 1,1} \beta_{1, l i} \Delta(\text { TUNINDEX })_{t-i}+\sum_{i=1}^{q 1,1} \beta_{1,2 i} \Delta(D E F)_{t-i}+\sum_{i=1}^{q 1,2} \beta_{1,3 i} \Delta(M 2)_{t-i} \\
+\sum_{i=1}^{q 1,3} \beta_{1,4 i} \Delta(I N T)_{t-i}+\sum_{i=1}^{q 1,4} \beta_{1,5 i} \Delta(I N F L)_{t-i}+\sum_{i=1}^{q 1,5} \beta_{1,6 i} \Delta(E X C)_{t-i}+\sum_{i=1}^{q 1,6} \beta_{1,7 i} \Delta(M P I)_{t-i} \\
+\sum_{i=1}^{q 1,7} \beta_{1,8 i} \Delta(N R E S)_{t-i}+\sum_{i=1}^{q 1,8} \beta_{1,9 i} \Delta(\text { UNEMP })_{t-i}+\epsilon_{1 . t}
\end{gathered}
$$

After establishing the long-run dynamics, the next step is to capture the short-run relationship between selected variables by estimating an error correction model. This is given by the equation as below:

$$
\begin{gathered}
\Delta(\text { TUNINDEX })_{t}=\mu_{1,0}+\sum_{i=1}^{P 1,1} \mu_{1, l i} \Delta(\text { TUNINDEX })_{t-i}+\sum_{i=1}^{Q 1,1} \mu_{1,2 i} \Delta(D E F)_{t-i}+\sum_{i=1}^{Q 1,2} \mu_{1,3 i} \Delta(M 2)_{t-i}+\sum_{i=1}^{Q 1,3} \mu_{1,4 i} \\
\Delta(I N T)_{t-i}+\sum_{i=1}^{Q 1,4} \mu_{1,5 i} \Delta(I N F L)_{t-i}+\sum_{i=1}^{Q 1,5} \mu_{1,6 i} \Delta(E X C)_{t-i}+\sum_{i=1}^{Q 1,6} \mu_{1,7 i} \Delta(M P I)_{t-i}+ \\
\sum_{i=1}^{Q 117} \mu_{1,8 i} \Delta(\text { NRES })_{t-i}+\sum_{i=1}^{Q 1,8} \mu_{1,9 i} \Delta(\text { UNEMP })_{t-i}+E C T_{1, t}
\end{gathered}
$$


Where ECT represents the error correction terms indicating the speed adjustment to the long-term equilibrium. Negative and significant coefficient shows the existence of stable long-term relationship.

\section{Empirical Results}

This section reports our empirical findings. We begin with the descriptive statistics and correlation analysis. Afterwards, we present results of unit root test and bound test and in the end, we analyze the long-run relationship and the short-term dynamics between our selected variables.

\subsection{Descriptive Statistics}

Table 2 exhibits descriptive analysis of all variables selected for our study over a period of seven years, whether 84 observations for variables expressed on real value (INT, INFL and EXC) and 83 observations for all other variables expressed on growth rate.

By analyzing the Jarque-Bera statistic, we remark that almost variables (M2, INT, INFL, NRES and TUNINDEX) are normally distributed. However, Jarque-Bera statistics for the series (DEF, EXC, MPI and UNEMP) are statistically significant which allows us to clearly reject the null hypothesis of normality. Indeed, their coefficients of asymmetry (skewness) and kurtosis (kurtosis) are significantly different from the levels predicted by the normal distribution. The values of skewness coefficients are different from zero which supports asymmetric distributions. Series TUNINDEX is negatively skewed and longer tail towards left. However, budget deficit, exchange rate, mine production index and number of unemployed graduates are positively skewed implying that their distributions spread to the right.

Similarly, kurtosis coefficients are all different from three. The series data of budget deficit, mine production index and stock price index are leptokurtic distributed, kurtosis is greater than 3 . Nevertheless, for the exchange rate and the number of unemployed graduates, their kurtosis coefficient value is less than three underlying the character platykurtic.

Table 2. Descriptive statistics

\begin{tabular}{lccccccccc}
\hline & TUNINDEX & DEF & M2 & INT & INFL & EXC & MPI & NRES & UNEMP \\
\hline Mean & 0.876 & 6.405 & 0.815 & 4.450 & 4.794 & 1.994 & 1.948 & 3.606 & 1.139 \\
Median & 1.014 & 2.984 & 0.830 & 4.520 & 4.983 & 1.953 & 0.000 & 5.673 & 0.96 \\
Max & 11.036 & 97.562 & 3.260 & 5.310 & 6.514 & 2.317 & 85.393 & 58.151 & 21.079 \\
Min & -13.290 & -55.341 & -1.782 & 3.160 & 2.846 & 1.752 & -70.816 & -57.232 & -9.819 \\
Std.Dev & 4.249 & 18.351 & 1.058 & 0.544 & 1.032 & 0.154 & 24.23 & 25.686 & 2.983 \\
Skwness & -0.359 & 2.057 & 0.275 & -0.558 & -0.271 & 0.631 & 0.695 & -0.183 & 2.668 \\
Kurtosis & 4.233 & 12.234 & 3.035 & 2.808 & 1.851 & 2.273 & 5.892 & 2.256 & 28.446 \\
Jarque-Bera & 7.050 & 353.451 & 1.054 & 4.503 & 5.648 & 7.429 & 35.615 & 2.379 & 2337.947 \\
Prob & 0.029 & 0.000 & 0.590 & 0.105 & 0.059 & 0.024 & 0.000 & 0.304 & 0.000 \\
Obs & 83 & 83 & 83 & 84 & 84 & 84 & 83 & 83 & 83 \\
\hline
\end{tabular}

\subsection{Correlation Analysis}

To avoid the multi-colinearity problem, we tested the bivariate correlation of explanatory variables. Two correlated variables should not be included in the same model since they can prevaricate results. In this sense, the multi-colinearity phenomenon exists only when the correlation coefficient value between two variables exceeds the critical value 0.50 .

Table 3 displays correlation among explanatory variables.

Table 3. Correlation matrix

\begin{tabular}{lllllllll}
\hline & DEF & M2 & INT & INFL & EXC & MPI & NRES & UNEMP \\
\hline DEF & 1 & & & & & & & \\
M2 & 0.064 & 1 & & & & & & \\
INT & 0.343 & 0.109 & 1 & & & & & \\
INFL & -0.039 & -0.068 & -0.083 & 1 & & & & \\
EXC & -0.418 & -0.137 & 0.042 & 0.665 & 1 & & & \\
MPI & -0.037 & 0.116 & -0.061 & 0.089 & -0.008 & 1 & & \\
NRES & 0.085 & 0.105 & 0.026 & 0.013 & -0.059 & 0.237 & 1 & \\
UNEMP & 0.229 & 0.182 & 0.289 & -0.285 & -0.228 & -0.122 & -0.117 & 1 \\
\hline
\end{tabular}


Correlation coefficients for all explanatory variables range between 0.418 and 0.665 . All values are less than 0.5 except for two variables INFL and EXC. They recorded a high positive coefficient in order of 0.665 . For this, we will introduce all the variables together in our model after excluding the variable EXC.

\subsection{Unit Root Analysis}

Before estimating our ARDL model and in order to ignore any spurious regression, we tested the stationarity of different series to ensure that none of them is integrated of order two (I (2)) or more. Indeed, the 'bounds test "procedure is invalid in the presence of variables integrated of order two or more.

Table 4. Unit root test for stationnary

\begin{tabular}{ccccccc}
\hline Variables & \multicolumn{3}{c}{ At level } & \multicolumn{3}{c}{ At first difference } \\
\cline { 2 - 7 } & $\begin{array}{c}\text { Intercept and } \\
\text { trend }\end{array}$ & $\begin{array}{c}\text { Intercept no } \\
\text { trend }\end{array}$ & None & $\begin{array}{c}\text { Intercept and } \\
\text { trend }\end{array}$ & $\begin{array}{c}\text { Intercept no } \\
\text { trend }\end{array}$ & None \\
\hline TUNINDEX & -4.483 & -4.510 & -4.327 & -9.386 & -9.427 & -9.491 \\
& $(0.0029)^{* * *}$ & $(0.0004)^{* * *}$ & $(0.0000)^{* * *}$ & $(0.0000)^{* * *}$ & $(0.0000)^{* * *}$ & $(0.0000)^{* * *}$ \\
DEF & -4.112 & -3.950 & -3.979 & -14.099 & -14.155 & -14.123 \\
& $(0.0090)^{* * *}$ & $(0.0027)^{* * *}$ & $(0.0001)^{* * *}$ & $(0.0001)^{* * * *}$ & $(0.0001)^{* * *}$ & $(0.0000)^{* * *}$ \\
M2 & -7.300 & -6.330 & -0.891 & -5.568 & -5.680 & -5.676 \\
& $(0.0000)^{* * *}$ & $(0.0000)^{* * *}$ & $(0.3267)$ & $(0.0001)^{* * *}$ & $(0.0000)^{* * *}$ & $(0.0000)^{* * *}$ \\
INT & -2.028 & -2.189 & -0.490 & -7.102 & -6.942 & -6.977 \\
& $(0.5771)$ & $(0.2116)$ & $(0.5006)$ & $(0.0000)^{* * * *}$ & $(0.0000)^{* * *}$ & $(0.0000)^{* * *}$ \\
INFL & -1.484 & -0.848 & 0.640 & -4.703 & -4.906 & -4.867 \\
& $(0.8260)$ & $(0.7988)$ & $(0.8523)$ & $(0.0016)^{* * *}$ & $(0.0001)^{* * *}$ & $(0.0000)^{* * *}$ \\
MPI & -11.167 & -11.242 & -11.188 & -5.875 & -5.909 & -5.942 \\
& $(0.0000)^{* * *}$ & $(0.0001)^{* * *}$ & $(0.0000)^{* * *}$ & $(0.0000)^{* * *}$ & $(0.0000)^{* * *}$ & $(0.0000)^{* * *}$ \\
NRES & -3.086 & -3.147 & -1.128 & -7.523 & -7.569 & -7.628 \\
& $(0.1175)$ & $(0.0275)^{* *}$ & $(0.2332)$ & $(0.0000)^{* * *}$ & $(0.0000)^{* * *}$ & $(0.0000)^{* * *}$ \\
UNEMP & -3.687 & -3.133 & -2.314 & -3.414 & -3.441 & -3.461 \\
& $(0.0298)^{* *}$ & $(0.0286)^{* *}$ & $(0.0209)^{* * *}$ & $(0.0578)^{* *}$ & $(0.0127)^{* * *}$ & $(0.0008)^{* * * *}$ \\
\hline
\end{tabular}

Note. *,** and *** implies significance at 10,5 and 1 percent levels.

Table 4 summarizes the results of unit root test (ADF) at level and first difference under assumption of intercept and trend, intercept and none. Results indicate that all variables are integrated of order zero at level except INT and INFL which became stationary after first differencing.

\subsection{Bound Testing}

After identifying the mixed order of integration of variables $(\mathrm{I}(0))$ and $\mathrm{I}(1)$ ), we proceed for testing cointegation between variables.

Table 5 below underlines results of bound test for cointegration.

Table 5. ARDL bound test

\begin{tabular}{llllllll}
\hline & & \multicolumn{2}{c}{$\begin{array}{c}\text { Critical value at 1 percent level of } \\
\text { significant }\end{array}$} & \multicolumn{2}{c}{$\begin{array}{c}\text { Critical value at 5 percent level } \\
\text { of significant }\end{array}$} & \multicolumn{2}{c}{$\begin{array}{c}\text { Critical value at 10 percent level } \\
\text { of significant }\end{array}$} \\
\cline { 2 - 9 } $\mathrm{K}$ & $\mathrm{F}$ & $\mathrm{I}(0)$ & $\mathrm{I}(1)$ & $\mathrm{I}(0)$ & $\mathrm{I}(1)$ & $\mathrm{I}(0)$ & $\mathrm{I}(1)$ \\
\hline 7 & 9.008 & 2.96 & 4.26 & 2.32 & 3.5 & 2.03 & 3.13 \\
\hline
\end{tabular}

Since the calculated F-statistic is greater than the highest Bound I(1), we can clearly reject the null hypothesis of no cointegation. This shows that there is a long-run relationship among macroeconomic, demographic indicators and the Tunisian stock market index.

\subsection{Long-Run Relationship Analysis}

Table 6 presents the long-run cointegration relationship between macroeconomic, demographic variables and the Tunisian stock market index (TUNINDEX). Results reveal that budget deficit, money supply, inflation rate, number of non-resident entries and number of unemployed graduates have a significant long-term effect on the 
Tunisian stock market index, while, interest rate and mine production index are statistically insignificant.

Table 6. Long run coefficients using ARDL approach (Dependent variable is TUNINDEX)

\begin{tabular}{lllll}
\hline Variable & Coefficient & Std. Error & T-statistic & P-value \\
\hline DEF & -0.072475 & 0.026927 & -2.691533 & $0.0093 * * *$ \\
M2 & 3.211277 & 0.869455 & 3.693436 & $0.0005 * * *$ \\
INT & -0.741920 & 0.625429 & -1.186258 & 0.2404 \\
INFL & -1.135341 & 0.308819 & -3.676397 & $0.0005 * * *$ \\
MPI & 0.016074 & 0.013150 & 1.222313 & 0.2266 \\
NRES & 0.052422 & 0.014929 & 3.511382 & $0.0009 * * *$ \\
UNEMP & -0.835242 & 0.176590 & -4.729839 & $0.0000^{* * *}$ \\
C & 7.737027 & 2.522345 & 3.067394 & $0.0033^{* * *}$ \\
\hline
\end{tabular}

Note. *,** and *** denote significance at 10,5 and 1 percent levels.

As expected, budget deficit had an adversely effect on the Tunisian stock market, indicating that one percent increase in DEF, leads to decrease the TUNINDEX by 0.072 percent. This result supports previous finding of (Greenspan \& Allen, 1995; Ball \& Mankiw, 1995; Quayes, 2010, Joshi \& Kumar, 2015), who investigated a negative relationship between budget deficit and stock market.

Besides, a significantly positive long-run relationship is found between money supply and stock market index. The increase in money supply causes the increase of liquidity which leads to a higher demand for assets and thus equity price rises. Our result corroborates the evidence of (Ratanapakorn \& Sharma, 2007; Hosseini et al., 2011; Hussain et al., 2012; Forson \& Janrattanagu, 2013).

Interest rate seems to have any effect on the Tunisian stock market. Our evidence is inconsistent with the explanation that the rise of interest rate leads to a drop in equity prices.

However, the increase in inflation rate contributes to the decrease of the Tunisian stock market index by 1.135 percent, which confirms empirical finding of (Malkiel, 1982; Fama, 1981; Lintner, 1973; Jaffe \& Mandelker, 1977; Fama \& Schwert, 1977; Akbar et al., 2012; kim, 2003). Indeed, unexpected inflation increase may increase uncertainty about the economy, which can lead to lower earning expectations of companies and therefore a fall in stock prices.

As for mine production index, results show that the estimated coefficient is statically insignificant. So, the mine production index seems to have no effect on the TUNINDEX. This results fall in line with the previous research of (Naik \& Padhi, 2012; Nishat \& Shaheen, 2004; Al-Adaylah, 2015) which suggest a positive relationship between industrial production and stock prices.

Moreover, the number of non-resident entries is significantly and positively associated to stock prices. The rise of the number of non-resident entries by 1 percent increases the Tunisian stock market index by 0.052 percent. Indeed, the rise of the numbers of non-resident entries leads to increase consumption and demand for goods and services, leading to higher earnings and stock prices.

The long-run cointegation relationship also shows that the number of unemployment graduates had a negative effect on stock prices. Besides, the rise of the number of unemployed graduates by one percent reduces the Tunisian stock market index by 0.835 percent. Our result is consistent with the explanation that the increase of the number of unemployed graduates leads to a decrease in demand for good and services, and as a result, firms' profits and stock prices will drop.

\subsection{Short-Run Relationship Analysis}

Table 7 highlights the results of vector error correction model. The estimated coefficient of the error correction term is statistically significant and negative (-1.540895), implying a very high speed adjustment toward the long-term equilibrium following a short-run shock. Deviation from the long-run equilibrium is corrected by $1.54 \%$ in the current month. This finding attests the existence of a stable long-term relationship among variables.

Furthermore, variables such as money supply and second order difference of the number of unemployed graduates were positively linked, while, first and second order difference of money supply, inflation rate, first order difference of number of non-resident entries and the number of unemployed graduates were inversely related to the Tunisian stock market index in the short-term. 
Table 7. Short-run coefficients using ARDL approach (Dependent variable is TUNINDEX)

\begin{tabular}{|c|c|c|c|c|}
\hline Variable & Coefficient & Std. Error & T-statistic & P-value \\
\hline D(TUNINDEX (-1)) & 0.226150 & 0.112345 & 2.013004 & $0.0488 * *$ \\
\hline $\mathrm{D}(\mathrm{DEF})$ & -0.029467 & 0.041250 & -0.714348 & 0.4779 \\
\hline $\mathrm{D}(\mathrm{M} 2)$ & 1.336631 & 0.419420 & 3.186858 & $0.0023 * * *$ \\
\hline $\mathrm{D}(\mathrm{M} 2(-1))$ & -1.143397 & 0.450306 & -2.539154 & $0.0139 * *$ \\
\hline $\mathrm{D}(\mathrm{M} 2(-2))$ & -0.832094 & 0.440123 & -1.890597 & $0.0638^{*}$ \\
\hline $\mathrm{D}(\mathrm{M} 2(-3))$ & -0.692153 & 0.450955 & -1.534860 & 0.1304 \\
\hline $\mathrm{D}(\mathrm{INT})$ & -1.143220 & 0.972122 & -1.176005 & 0.2445 \\
\hline D(INFL) & -5.089344 & 1.711452 & -2.973699 & $0.0043^{* * *}$ \\
\hline D(MPI) & 0.024768 & 0.020531 & 1.206402 & 0.2326 \\
\hline $\mathrm{D}(\mathrm{NRES})$ & 0.006843 & 0.015944 & 0.429200 & 0.6694 \\
\hline D(NRES (-1)) & -0.047525 & 0.016466 & -2.886167 & $0.0055^{* * *}$ \\
\hline D(UNEMP) & -0.470707 & 0.175907 & -2.675889 & $0.0097 * * *$ \\
\hline D(UNEMP (-1)) & -0.154785 & 0.176668 & -0.876134 & 0.3846 \\
\hline D(UNEMP (-2)) & 0.347203 & 0.156292 & 2.221503 & $0.0303 * *$ \\
\hline ECT(-1) & -1.540895 & 0.183937 & -8.377318 & $0.0000 * * *$ \\
\hline
\end{tabular}

Note. $*, * *$ and $* * *$ denote significance at 10,5 and 1 percent levels.

\subsection{Diagnostic Checking}

To ensure the robustness of our ARDL model, several diagnostic tests like normality, serial correlation, heteroscedasticity and functional form were performed.

Table 8. Diagnostic test

\begin{tabular}{lll}
\hline Item & Test applied & Prob \\
\hline Normality & Jarque bera & 0.6537 \\
Serial correlation & Lagrange multiplier test & 0.4236 \\
Heteroscedasticity & White test & 0.5481 \\
Functional form & Ramsey's RESET test & 0.2324 \\
\hline
\end{tabular}

Above results indicate that all econometric problems have not been detected. Models residuals are normally distributed, serially uncorrelated and homoscedastic. Similarly, the model is correctly specified with reference to functional form test.

\section{Conclusion}

This paper examine both the long-run and the short-run relationship between macroeconomic indicators such as budget deficit, money supply, interest rate, inflation rate, exchange rate and mine production index, demographic factors namely the number of non-resident entries and the number of unemployed graduates and the Tunisian stock market index for the period subsequent to the financial crisis. Monthly data over the period 2008-2014 and ARDL approach based on bound testing have been employed.

Results indicate that the Tunisian stock market index, macroeconomic and demographic indicators are cointegrated and, therefore, a long-run relationship exists between them.

The long-run relationship suggests that budget deficit, inflation rate and the number of unemployed graduates had a negative, otherwise, money supply and the number of non-resident entries had a positive effect on the Tunisian stock market. Moreover, the short-run dynamics shows that the Tunisian stock market index is influenced positively by money supply and second order difference of the number of unemployed graduates and negatively by first and second order difference of money supply, inflation rate, first order difference of number of non-resident entries and the number of unemployed graduates.

In term of policy implication, our empirical study gives us insight on a set of macroeconomic and demographic factors determining the Tunisian stock market index. These indicators identified provide useful signals on the evolution of stock price and their monitoring could contribute to a greater stability in stock market. Hence, these findings might be beneficial for national policymakers and investors. 


\section{References}

Akbar, M., Ali, S., \& Khan, M. F. (2012). The Relationship of Stock Prices and Macroeconomic Variables revisited: Evidence from Karachi Stock Exchange. African Journal of Business Management, 6(4), 1315-1322. http://dx.doi.org/10.5897/AJBM11.1043

Al-Adayleh, R. M. (2015). Investigation the Equilibrium Relationship Between Micro and Macroeconomic Variables and Amman Stock Exchange (ASE) Index Through ARDL Model (The Bound Test Approach). International Journal of Business and Statistical Analysis, (1), 55-61. Retreived from http://www.uob.edu.bh/uob_files/760/vol\%202-1/paper5.pdf

Alam, Md. M. (2009). Relationship between Interest Rate and Stock Price: Empirical Evidence from Developed and Developing Countries. International Journal of Business and Management, 4(3), 43-51. http://dx.doi.org/10.5539/ijbm.v4n3p43

Ball, L., \& Mankiw, N. G. (1995). What Do Budget Deficit Do? National Bureau of Economic Research 5263, 1-36. http://dx.doi.org/10.3386/w5263

Cheung, Y. W., \& Lai, K. (1993). Fractional Co-Iintegration Analysis of Purchasing Power Parity. Journal of Business and Economic Statistics, 1, 103-112. http://dx.doi.org/ 10.1080/07350015.1993.10509936

Fama, E. (1970). Efficient Capital Markets: A Review of Theory and Empirical Work. Journal of Finance, 25(2), 383-417. http://dx.doi.org/10.2307/2325486

Fama, E. (1981). Stock Returns, Real Activity, Inflation and Money. American Economic Review, 71(4), 545-565.

Fama, E. F., \& Schwert, G. W. (1977). Asset Returns and Inflation. Journal of Financial Economics, 5(2), 115-146. http://dx.doi.org/10.1016/0304-405X(77)90014-9

Forson, J., \& Janrattanagu, J. (2013). Selected Macroeconomic Variables and Stock Market Movements: Empirical Evidence from Thailand. Comtemporary Economics, 8(2), 154-174. http://dx.doi.org/10.5709/ce.1897-9254.138

Greenspan, A. (1995). What Do Budget Deficits Do? General Discussion, Budget Deficits and Debt: Issues and Options. Federal Reserve Bank, 139-149.

Hamrita, M., \& Trifi, A. (2011). The Relationship between Interest rate, Exchange Rate and Stock Price: A Wavelet Analysis. International Journal of Economics and Financial Issues, I(4), 220-228. Retreived from http://econjournals.com/index.php/ijefi/article/download/47/pdf

Henchiri, J. E. (2010). Financial crisis, Governance and Risk management. Journal of Academic Finance, special Issue. Retrieved from http://www.scientifics.fr/journal/index.php/AF/issue/view/11/showToc

Hosseini, S. M., Ahmad, Z., \& Lai, W. Y. (2011). The Role of Macroeconomic Variables on Stock Market Index in China and India. International Journal of Economics and Finance, 3(6), 233-234. http://dx.doi.org/10.5539/ijef.v3n6p233

Hussain, M. M., Aamir, M., Rasool, N., Fayyaz, M., \& Mumtaz, M. (2012). The Impact of Macroeconomic Variables on Stock Prices: An Empirical Analysis of Karachi Stock Exchange. Mediterranean Journal of Social Sciences, 3(3), 295-312. http://dx.doi.org/10.5901/mjss.2012.v3n3p295

Islam, S. M. N., Watanapalachaikul, S., \& Billington, N. (2004). A Time Series Analysis and Modelling of Thai Stock Market. UNITEN International Business Management Conference, Selangor: University Tenaga Nasional, $\quad$ pp. 91-98. $\quad$ Retrieved from http://dspace.uniten.edu.my/bitstream/123456789/624/1/A\%20time\%20series\%20analysis\%20and\%20mod elling\%20of\%20the\%20Thai\%20stock\%20market.pdf

Jaffe, J. F., \& Mandelker, G. (1977). The Fisher Effect for Risky Assets: An Empirical Investigation. Journal of Finance, 31, 447-458. http://dx.doi.org/10.2307/2326616

Joshi, P., \& Kumar, G. (2015). Fiscal Deficits and Stock Prices in India: Empirical Evidence. Int. J. Financial Studies, 3, 393-410. http://dx.doi.org/10.3390/ijfs3030393

Kalyanaraman, L., \& Al-Tuwajri, B. (2014). Macroeconomic Forces and Stock Prices: Some Empirical Evidence from Saudi Arabia. International Journal of Financial Research, 5(1), 81-92. http://dx.doi.org/10.5430/ijfr.v5n1p81

Kim, K. (2003). Dollar Exchange Rate and Stock Price: Evidence from Multivariate Cointegration and Error 
Correction Model. Review of Financial Economics, 12, 301-313. http://dx.doi.org/10.1016/S1058-3300(03)00026-0

Lintner, J. (1973). Inflation and Common Stock Prices in a Cyclical Context. National Bureau of Economic Research Annual Report.

Mahmudul, A., \& Gazi, S. U. (2009). The Relationship between Interest Rate and Stock Price: Empirical Evidence from Developed and Developing countries. International Journal of Business and Management, 4(3), 43-51. http://dx.doi.org/10.5539/ijbm.v4n3p43

Malkiel, B. G. (1982). Risk and Return: A new look. National Bureau of Economic Research Cambridge, Mass., USA. http://dx.doi.org/10.3386/w0700

Mukherjee, T. K., \& Naka, A. (1995). Dynamic Relations between Macroeconomic Variables and the Japanese Stock Market: An application of a vector error-correction model. The Journal of Financial Research, 18(2), 223-237. http://dx.doi.org/10.1111/j.1475-6803.1995.tb00563.x

Naik, P. K., \& Padhi, P. (2012). The Impact of Macroeconomic Fundamentals on Stock Prices Revisited: Evidence from Indian Data. Eurasian Journal of Business and Economics, 5(10). Retrieved from https://mpra.ub.uni-muenchen.de/38980/2/MPRA_paper_38980.pdf

Nishat, M., \& Shaheen, N. (2004). Macroeconomic Factors and Pakistani Equity Market. Department of Finance and Economics, Institute of Business Administration Karachi, Pakistan, 57, 144-46.

Quayes, S. (2010). Does Budget Deficit Lower Equity Prices in USA. Elsevier 107, 155-157. http://dx.doi.org/10.1016/j.econlet.2010.01.011

Ratanapakorn, O., \& Sharma, S. C. (2007). Dynamics Analysis Between the US Stock Return and the $\begin{array}{lllll}\text { Macroeconomics Variables. Applied } & \text { Financial Economics, 17(4), 369-377. }\end{array}$ http://dx.doi.org/10.1080/09603100600638944

Sarbapriya, R. (2013). Towards Examining the Relationship between Industrial Production and Stock Price in India. United States of America Research Journal (USARJ), 1(3), 36-45.

\section{Copyrights}

Copyright for this article is retained by the author(s), with first publication rights granted to the journal.

This is an open-access article distributed under the terms and conditions of the Creative Commons Attribution license (http://creativecommons.org/licenses/by/3.0/). 